\title{
Prof. Saffet Mutluer: President of the ISPN in 2009-2010
}

\author{
Concezio Di Rocco
}

Received: 23 June 2011 / Accepted: 23 June 2011

(C) Springer-Verlag 2011

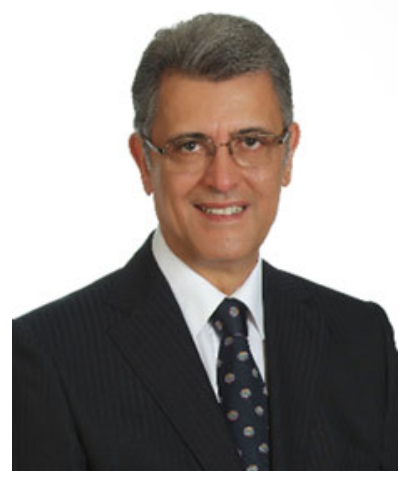

In the autumn of 2010, during the ISPN Annual Scientific Meeting in Jeju, Prof. Wang, the chairman of the meeting, gathered for the first time all of us who were lucky to have been educated at the Children's Memorial Hospital, Northwestern University of Chicago by Anthony J. Raimondi, subsequently by David McLone, and in more recent time, by Tadanori Tomita. The dinner Prof. Wang organized was actually the first meeting of what could be named the Chicago School Group and the occasion for several of us to recollect special memories. It is in the frame of the "Chicago School" that I had met our president, his charming wife Inci, and their pleasant and smart sons several years before. Actually, the picture of Saffet in David McLone's office marked the transition between the Raimondi and McLone leaderships, as he was David's first foreign resident.

C. Di Rocco $(\bowtie)$

Section of Pediatric Neurosurgery,

Catholic University Medical School,

Rome, Italy

e-mail: cdirocco@rm.unicatt.it

Saffet Mutluer was born in Pasinler, Turkey in 1948. His father was an army officer; therefore, he was only able to finish his primary, secondary, and high school education for 11 years in 1966, having changed nine different places. When he was a child, he was fascinated by the skies; he wanted to be a pilot. However, when his uncle, who was a pilot in the air forces, died because of a plane crash, his family was utterly against his wish of becoming one.

In a man's life, there are two important milestones which will guide him in his future. One is his choice of employment and the other one is his choice of his wife.

His grandfather, of whom he was named after, could not fulfil his wish of becoming a medical doctor, when he was conscripted during World War I. When Saffet's father was in military high school and about to join the military school of medicine, this time World War II prevented him from doing so. His family's wishes must have driven him, so he started at Ege University's Faculty of Medicine in 1966. He was a successful student in his university years; surgical branches always attracted him. In 1969, when his father had a lumbar disc surgery, he met Dr. Erdem Tunçbay, who had come from Northwestern University to Ege University to establish the Department of Neurosurgery. In 1972, when he graduated from Ege University's Faculty of Medicine, he went to Dr. Tunçbay to specialize in neurosurgery. When Dr. Tunçbay asked him, "Neurosurgery takes a lot of sacrifice and is very stressful, have you considered it well?", he answered shortly "Yes, I'm ready for it."

The second most important event in his life would be meeting Inci Turkmen. As Saffet told me, the initial indifference they felt when they met for the first time when their families got together later turned into love. When he was proposing, Saffet had told Inci how hard and intense his job was and when he later asked Inci, "Would you be my partner for life?", she answered, "I knew why you 
brought me here, my anticipated answer is yes." The proposal took place in one of the most famous restaurants in Izmir, their hometown, where they entered with a solemn anticipation and left arm in arm, united for life. In his first year of residency, they stayed engaged for a short while and got married in 15 April 1973 (Fig. 1).

His first years of neurosurgical training were very intense and heavy. Life went on as he spent $56 \mathrm{~h}$ at the hospital, $12 \mathrm{~h}$ at home consecutively, and sometimes he spent a continuous week doing hard work as the resident on call at the intensive care unit in hospital. However, the Muetlers tried to lead a proper social life, although Saffet would fall asleep in the theatre opera or at the movies from time to time. Their son, Bilge, was born in 1974 and their daughter, Burcu, in 1976, and both were quite deprived of their father because of his heavy neurosurgical training. (Inci Mutluer was invited to the Turkish Neurosurgical Society's Annual Meeting as a speaker in 1999, where she had given a highly memorable speech titled "Being the Wife of a Neurosurgeon," telling of these hardships.) Besides being a wonderful orator - all of us certainly remember her formidable speech at the social banquet during the recent Jeju meeting - and an active promoter of women emancipation in her country, Inci is also an unbelievable driver.

In 1992, Saffet invited Dr. David McLone (Fig. 2) to the Annual Meeting of the Turkish Neurosurgical Society (TNS) which was held in Cappadocia. Inci was driving when they went from Cappadocia to Izmir. David still tells of the story of how Inci was not driving, but flying.

I still remember when she drove me back to Çesme from a visit to Pergamon at a constant speed of $180 \mathrm{~km} / \mathrm{h}$ and I asked her whether the motorway had to close at a given time to explain such a "fast and furious" trip. Actually, sunset in Çesme is particularly beautiful and Inci was trying to catch it. It is worth to note that such a "Ferrari" performance was done by Inci with a broken foot as she had previously fallen during the visit to Pergamon in a

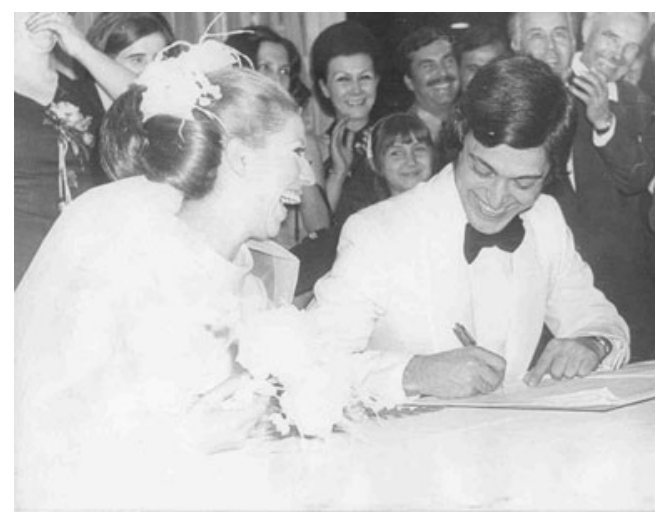

Fig. 1 Inci and Saffet at their wedding ceremony

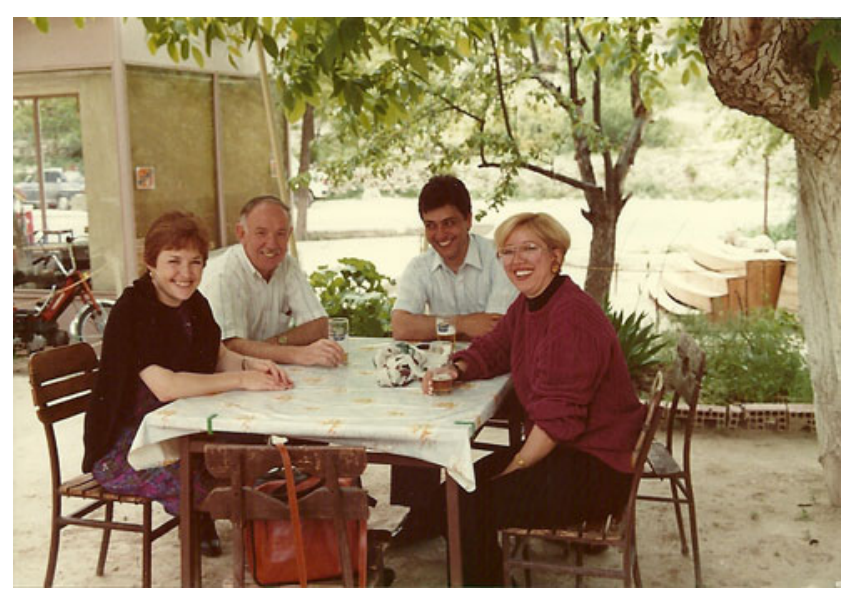

Fig. 2 Noreen and David G. Mclone, Saffet and Inci Mutluer at Cappadocia Turkey in 1992

hidden crater, probably abstracted by my descriptions about the archaeological ruins.

In 1977, Saffet Mutluer became a medical specialist on neurosurgery and carried on with his work in Ege University. Prof. Tuncbay had envisioned that the development of neurosurgery would be in sections, and with his love for children and Inci's motivation, Saffet pursued pediatric neurosurgery. He was appointed in a pediatric neurosurgery unit in Ege University consisting of six beds, and he started operations also at Behçet Uz Children's Hospital.

In order to improve his knowledge and himself and to meet with Prof. Raimondi, he started contacting him, when a very important event caused him to reconsider his decision. A friend of Prof. Tuncbay had died in a traffic accident, and his wife and son were seriously injured in Antalya. At that time, there was no neurosurgeon in their place; therefore, he was sent there to help them. He picked up his surgical equipment and angiography sets and went there. He was the first to perform a cerebral angiography in Antalya, and there was no need for an operation. The next morning, he was told how rich he would become if he were to stay in Antalya. On one side, a large sum of money, on the other, his ideal, pediatric neurosurgery. This was a dilemma, and because Inci knew what would truly make her husband happy, she kept supporting the idea of pediatric neurosurgery at all costs. Then, he had received an affirmative response from Prof. Raimondi. When he was preparing to go to Chicago in 12 September 1980, a coup d'état took place in Turkey. He was only allowed to go with a special permission to Chicago, leaving his wife and two children in their hometown, Izmir.

At that period in time, in Northwestern University's (NWU) Children's Memorial Hospital (CMH), Dr. David G. McLone had become the head; Dr. Raimondi was NWU's head of the Department of Neurosurgery and was 
Fig. 3 Saffet Mutluer at CMH
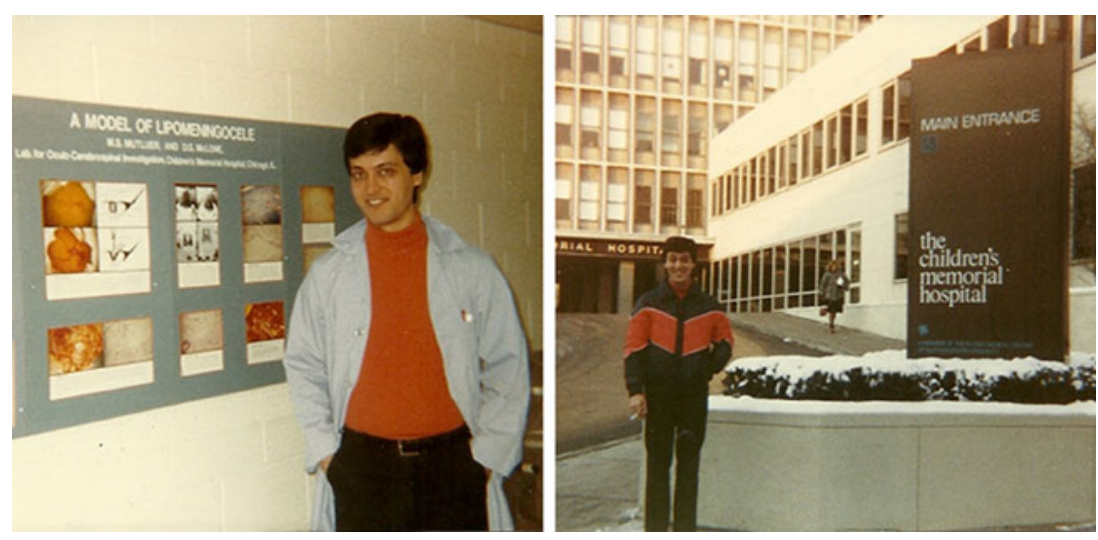

making the educational rounds there weekly. Tad Tomita was sent to Sloan Kettering Hospital in New York for his neuro-oncology training. Yoon Soon Hahn and Jack Brown were also in $\mathrm{CMH}$ as attending doctors. There would be 7 o'clock visits, 8 o'clock radiology meetings with Thomas P. Naidich, after that, surgical observations, Dr. DelCanto's frozen section examinations, MM clinic with Dr. David McLone, Dr. Raimondi's teaching rounds with tough questions every Thursdays, waking up in Joseph Brennemann Library, and writing letters to Inci and grand round at NWU Memorial in downtown on Saturdays. He had his hands full.

At that time, he became good friends with Yasuo Yamanouchi, from Osaka, Japan, who came there under similar conditions. He also had left his wife and two children in his country. On one hand, they were learning about pediatric neurosurgery, on the other, they started an experimental research at the Laboratory for OculoCerebrospinal Investigations (LOCI). Paul Knepper, an ophthalmologist, was the head of LOCI. Yamanouchi was researching ventriculitis in mice, while Saffet was making research on chick embryos (Fig. 3), and they both helped with the other research projects that went on in the laboratory. Also, they helped out with Dr. David McLone's electron microscopy studies.

One day, when Saffet was examining the microscopical findings of his mechanically induced dysraphism studies in chick embryos, Dr. McLone screamed, "You found it!". Just like Archimedes' "Eureka!". The incisions made over the chick embryos glycogen body had made an ideal model of lipomeningocele. This research was submitted in 1981 at NWU's Alumni Day and won the Anne Addington Award. (This award was also given to D. G. McLone, Concezio Di Rocco, and Shizuo Oi previously.)

Then, the neuroanatomy lessons at NWU were given by Prof. A.J. Raimondi in the Department of Neurosurgery. Saffet worked as an instructor. It was a responsibility and also fun. Some students would tease him by plucking out from the bottom some cranial nerves on the brain sections and asked which one belonged to which cranial nerve.
In 1980, he attended to learn pediatric neurosurgery for a year and, as a result of a prolongation of experimental research studies, he returned to Izmir, Turkey in March 1983. In 1983, in ISPN's Goteborg meeting, he became the first Turkish member through Prof. Raimondi and Prof. McLone's proposal.

His return to Turkey would mark a milestone in the development of pediatric neurosugery. However, he faced two big shocks along with his arrival. The first one was finding out about the advanced-stage medulloblastoma of the granddaughter of his aunt. He operated on her, clearing out the posterior fossa tumor and placing a shunt, which was hard to find in Turkey under the martial law at the time. A high-risk medulloblastoma metastasized all over, in spite of the tireless efforts in Rx therapy in England. She was only able to live 9 months more.

The second shock came as his experimental research of Chiari malformation in chicks at LOCI was submitted as thesis for his associate professor degree examination. However, ridiculously, the jury held a long discussion whether this could make a viable neurosurgery thesis or not, and finally, it was accepted as one. During those hard times in the autumn of 1983 when his aunt's granddaughter entered her terminal stage with the medulloblastoma, he completed examinations and became an associate professor.

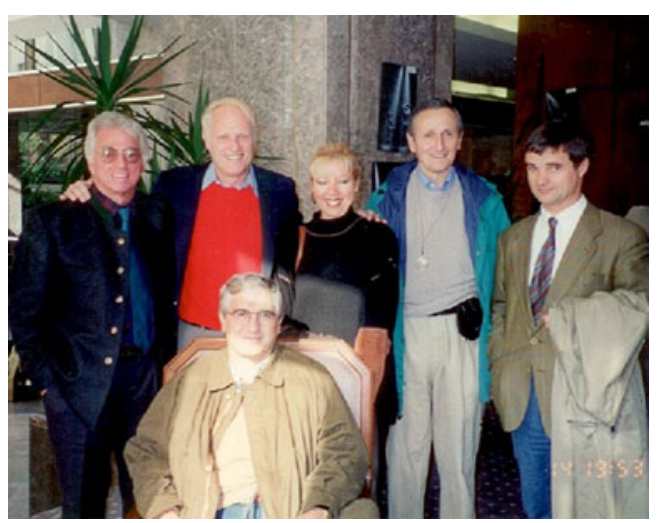

Fig. 4 Raimondi, Epstein, Inci Mutluer, Hoffman, Sorensen, and Di Rocco in 1993 during the TNS-PNG symposium 


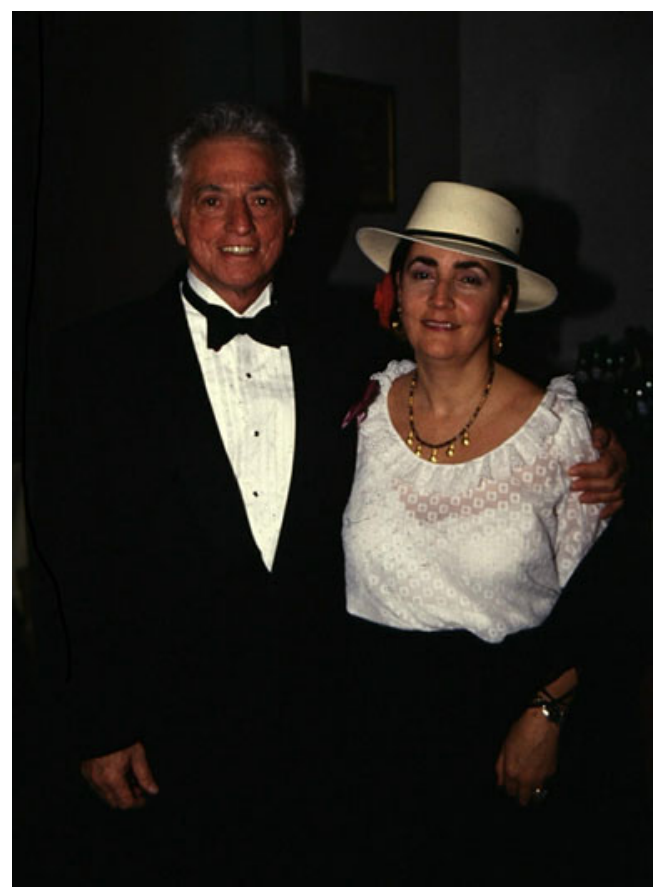

Fig. 5 Anthony and Lucia Raimondi at 1996 in Venice, during the Accademia meeting

His first move was to organize the Pediatric Neurosurgery Unit at Ege University and founded the craniofacial team with his plastic surgeon colleague.

In 1984, in ISPN's Cairo Meeting, everything was mixed up pretty badly, when the slide tray collapsed during his presentation of "Childhood Meningiomas." Still, Epstein and Hoffman both congratulated and consoled him at the end of the presentation. In that very meeting, his address to Satoshi Matsumoto, who had been introduced to him by Shizuo Oi, was an important step made in the name of international friendship, in spite of his little knowledge on Japanese language, which he had learned from Yamanouchi.
In 1983, the Ege University Department of Neurosurgery had moved to another building and the Unit of Pediatric Neurosurgery was assigned 15 beds. He sent Dr. Yusuf Ersahin, an acquaintance from his medical school years, to Chicago CMH, where Dr. David McLone was in 1987. Upon Yusuf's arrival in the following year, the pediatric neurosurgery in Ege University had gained more strength.

In 1989, Prof. Raimondi organized the first European symposium of "Pediatric Neurosurgery: State of Art" in Verona in Lago di Garda. Saffet represented Turkey in this meeting. He met with the future leaders of pediatric neurosurgery there. In the same year, he became a full professor in neurosurgery.

In 1992, Prof. Mutluer made pediatric neurosurgery a division in Ege University, and until he became the head of the Department of Neurosurgery at Ege University in 2003, he carried on being the head of the division. In 1993, he founded Ege University's MM team, and in 1996, he became the founding president of the Turkish Spina Bifida Society. In the same year, he invited Kemali Baykaner, Memet Ozek, and Yusuf Ersahin to Ege University to start the organization of pediatric neurosurgery in Turkey. They decided to found the Pediatric Neurosurgery Group (PNG) within the Turkish Neurosurgical Society. He was the founding president until 1999. For 3 years, yearly consensus meetings took place; later, it became a 3-year annual pediatric neurosurgery course and is still ongoing with its fifth term.

Further in the same year, he organized a Pediatric Neurosurgery Symposium in Izmir on behalf of the TNSPNG Group. A.J. Raimondi, F. Epstein, H. Hoffman, C. Di Rocco, C. Saint-Rose, and N. Soerensen (Fig. 4) participated in this very crowded and successful symposium which can be regarded as the milestone of the international relations of Turkish neurosurgery. Apart from his contribution to the development of pediatric neurosurgery in Turkey, he served as ESPN Publication Committee Chairman, Child's Nervous
Fig. 6 Saffet Mutluer ISPN President 2009-2010 and Inci Mutluer with Concezio Di Rocco
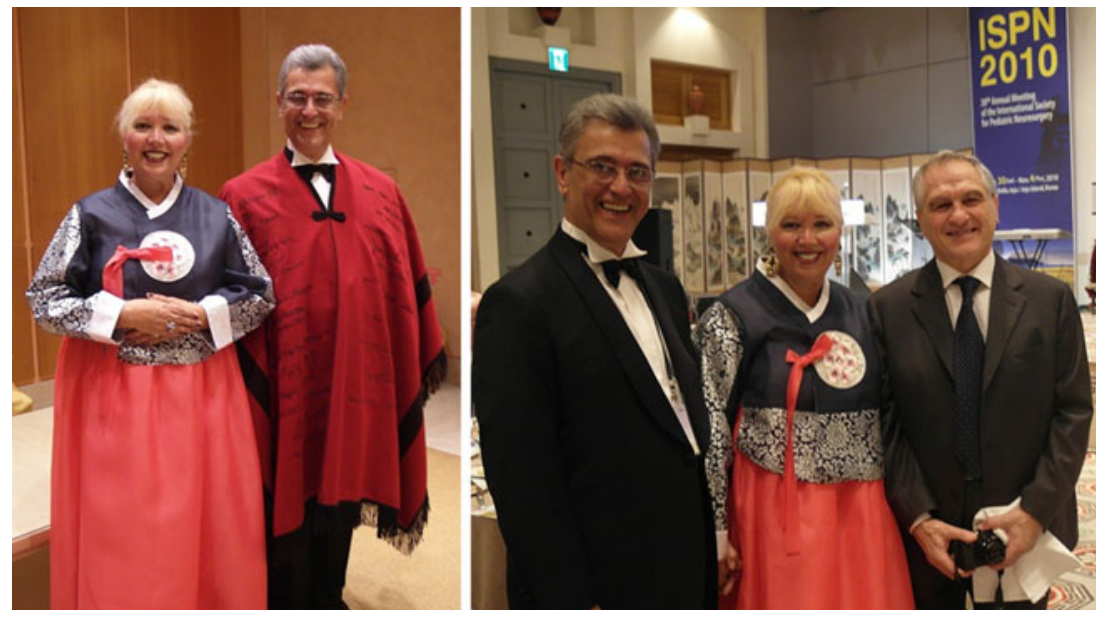
Fig. 7 a Mutluer family in 1993. b İnci, Saffet Mutluer, and their grandson Ege
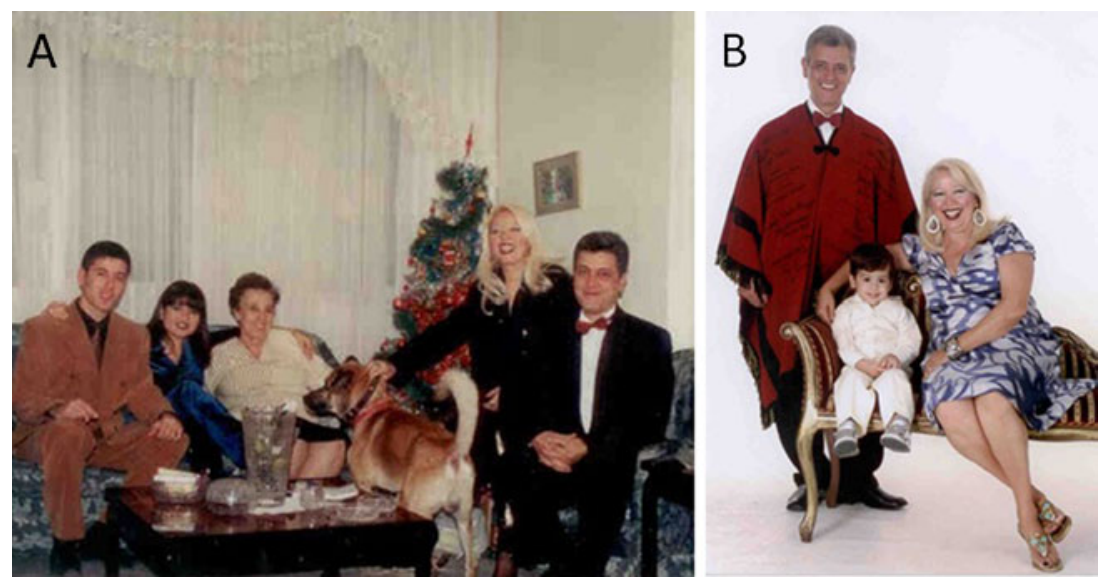

System editorial board member, ISPN Ethnic Liaison, Nominating Committees member, and as the Chairman of ISPN's Membership Committee during 2003-2006.

In 2000, he organized ISPN's 28th Annual Meeting in Istanbul. This congress made such an impact that it is still being talked about in every aspect. The Turkish bath adventures of ladies and gentlemen separately are still being told.

Since 1984, Saffet has been attending almost all ISPN congresses. In each congress, Inci represented all the modern aspects of her country with her social skills. I have to underline her many contributions to pediatric neurosurgery in Turkey and her enormous help and support to the ISPN Congress in 2000 in Istanbul. In 1996, in Dr. Raimondi's Accademia meeting in Venice (Fig. 5), she gave a presentation regarding the Anatolian civilizations in her speech titled "Bridge Between Cultures."

Saffet was elected as the next ISPN President in 2008, in ISPN's Cape Town meeting, and he wore a poncho in 2009, in Los Angeles, as ISPN's 38th president. In his term, a new web page for ISPN was developed; Executive Board Electronic Communication and its filing in archives and Electronic Voting System were started. In the ISPN's Jeju meeting in 2010 (Fig. 6), he passed over his title to Paul Steinbok. He is still active in the society as the nominating committee chair and past president.

Saffet Mutluer has written 93 journal articles, 8 book chapters, and made 177 oral and poster presentations. He is also a lecturer at ISPN courses. He received the 1982 NWU's Anne Addington Award and 2008 Turkish Neurosurgical Society's Service Award.

Saffet Mutluer has an active personality socially. He was TNS Vice President, a WFNS delegate of TNS, a founding member of Brain Spine Nerve Foundation in Izmir, and the President of Izmir Rotary Club during 2004-2005. Finally, I have to quote his main current hobby: Saffet loves to visit Singapore whenever he can because his daughter and grandson, Ege, are living there (Fig. 7). 